Vol. 44, N. 1 : pp. 95 - 99, March, 2001

ISSN 1516-8913 Printed in Brazil
BRAZILIAN ARCHIVES OF BIOLOGY AND TECHNOLOGY

AN INTERNATIONAL JOURNAL

\title{
Studies on Probiotics Properties of Two Lactobacillus Strains
}

\author{
María Antonieta Brizuela*, Paulina Serrano and Yovanka Pérez \\ Instituto Cubano de Investigaciones de los Derivados de la Caña de Azúcar (ICIDCA), P.O. Box 4026, La Habana, \\ Cuba
}

\begin{abstract}
"In vitro" studies were carried out for the selection of Lactobacillus strains with probiotics characteristics. Two strains of Lactobacillus were evaluated for the growth specific rate, generation time, acids, bile and antimicrobial resistances. "In vitro" tests indicated that the strains presented a potential for being used as probiotics.
\end{abstract}

Key words: Probiotics, Lactobacillus, selection

\section{INTRODUCTION}

The development of products with probiotic characteristics surges as a necessity of substituting the employment of antibiotics in animal feeding which are used to maintain a good balance of the gastrointestinal tract (GIT) microflora and to eliminate pathogenic microorganisms, facilitating the reduction of gastrointestinal upsets very frequent in animals. However antibiotics not only contribute to the destruction of beneficial gastrointestinal microflora but also produce residual effects in tissues and products of animal origin such as meat, eggs and milk. (Smoragiewicz et al., 1993).

Probiotic has been defined as a live or dead organism from Lactobacillus, Streptococcus, Enterococcus, Bacillus and Saccharomyces genera as well as microbial fermentation products, nucleotides and its metabolizable products, metabolites and organic acids (Ouwehand et al 1999).
Probiotics have been administered to animals in order to prevent infectious illness, reinforcing the barrier function of the intestinal flora or increasing the immune system. (Pascual et al., 1996).

Most probiotics contain lactic acid bacteria, because they are components of the natural microflora of almost all organisms, are rarely pathogenic and present antagonic properties against pathogenic microorganisms. (Fuller et al., 1992)

Newly born piglets posses a relatively rich are components of the natural microflora of almost all organisms, are rarely pathogenic and present antagonic properties against pathogenic microflora in their GIT occurring bacterial concentrations of $10^{7}-10^{9}$ microorganisms per gram of digesta in the small intestine. Lactic acid bacteria, mainly Lactobacillus and Streptococcus genera dominate the microflora. However modern methods of postnatal cares limit the contact with the mother, keeping the animals under artificial conditions

*Author for correspondence 
causing disturbs in the flora responsible for the resistance to illness. The use of probiotics in newly born piglets pretends not only to correct this deficiency without creating any other problems but also to re-establishing the full protective capacity of the GIT microflora.

Probiotics should be resistant to specific conditions occurring on the GIT, thus should be resistant for more than 4 hours to proteolytic enzymes, low $\mathrm{pH}$ values (1.8-3.2) prevailing in the stomach and to bile concentration, pancreatic juices and mucus which are part of the small intestine. Furthermore, bacterial strains to be used in probiotics obtention are supposed to be resistant to antibiotics eventually administered in animal diets and, are also to be a producers of antimicrobial substances such as lactic acid, hydrogen peroxide, bacteriocins, etc. (Gorbach \& Goldin, 1991; Hoyos, 1997)

The aim of this study was to evaluate the "in vitro" capacity of two Lactobacillus strains (LB12 and B/103-1-5) for their application as probiotics in animal feeding.

\section{MATERIAL AND METHODS}

Microorganisms and culture medium: The study was carried out using Lactobacillus sp. strain (LB-12) and Lactobacillus acidophilus strain (B/103-1-5) from ICIDCA Culture Collection. For counting as well as for cultivation, either the solid or liquid MRS medium (Man et $a l ., 1960)$ was used. MRS formulated with tomato juice, acetic acid and Oxgall Bile (MRS ${ }^{*}$ ) was employed for tolerance to bile assay (Gorbach et al., 1991)

Specific growth rate and generation time determination: Culture were grown in MRS medium $(700 \mathrm{~mL}$ in $1 \mathrm{~L}$ Erlenmeyer flasks) by inoculating with the cells at $10 \%(\mathrm{v} / \mathrm{v})$ and incubating at $37^{\circ} \mathrm{C}$ for 24 hours under partial $\mathrm{CO}_{2}$ (25\%) atmosphere Samples for estimating the growth and viable cells count were taken every two hour. Growth was estimated by dry weight measurement, and data were processed using lineal regression analysis.

Lactobacilli acid tolerance assay: Acid tolerance was tested using $30 \mathrm{~mL}$ MRS medium contained in $250-\mathrm{mL}$ erlenmeyers. The initial $\mathrm{pH}$ value was fixed at 3.0 with $\mathrm{HCl} 1 \mathrm{~N}$. Flasks were inoculated as above. Samples were taken at 0,12 and 24 hour to determine viable cells. Simultaneously a control at optimal growth $\mathrm{pH}$ was developed.

Bile tolerance assay: Bile tolerance was tested as above for acid tolerance.

Resistance to antimicrobial substances assays: Solutions with antimicrobial substances in the following concentrations were prepared: furasolidona $(10 \mathrm{mg} / 10 \mathrm{~mL})$, baijonot $(10 \mathrm{mg} / 10$ $\mathrm{mL})$, nitrovin $(20 \mathrm{mg} / 100 \mathrm{~mL})$, cooper sulphate $(20 \mathrm{mg} / 10 \mathrm{~mL})$ and dimetridazol $(100 \mathrm{mg} / 10 \mathrm{~mL})$. Test tubes of $8 \mathrm{~mL}$ of capacity containing MRS medium were inoculated with $16 \mathrm{~h}$ old culture and after adding $1 \mathrm{~mL}$ antimicrobial solutions were incubated for 24 hour employing the same conditions as above. Microbial growth (by optical density analysis) and viable cells counting were done at the end of the cultivation. Cells were also cultivated in a 5L Marubishi fermentator with $3 \mathrm{~L}$ of MRS medium under the similar conditions of $\mathrm{pH}$, temperature and inoculation.

Assays: Dry weight was carried out by centrifugation, and drying at $60^{\circ} \mathrm{C}$ until constant weight. Viable cells counting was performed by the serial dilution method and depth inoculation on MRS-agar media. Plates were incubated anaerobically at $37^{\circ} \mathrm{C}$ for 48 hours. Optical density measurements were made in a digital spectrophotometer (LKB) at $650 \mathrm{~nm}$ was used and total reducing sugar was done by 3,5 dinitro salicylic acid method. (Miller, 1959).

\section{RESULTS AND DISCUSSION}

\section{Specific growth rate and generation time:}

Table 1 - Specific growth rate and generation time of LB12 and $\mathrm{B} / 103-1-5$ strains at laboratory level.

\begin{tabular}{lccc}
\hline \multicolumn{1}{c}{ Strain } & $(\boldsymbol{\mu}), \mathbf{h}^{-1}$ & $\begin{array}{c}\text { Correlation } \\
\text { Coefficient }\end{array}$ & $\mathbf{T}_{\mathbf{G}}(\mathbf{h})$ \\
\hline LB-12 & 0.5480 & 0.9715 & 1.2 \\
B/103-1-5 & 0.4930 & 0.9871 & 1.4 \\
\hline$\mu$ : Specific growth rate & $\mathrm{T}_{\mathrm{G}}$ : Generation time
\end{tabular}


Specific growth rate and generation time of both strains are shown in Table 1. Strain LB-12 showed higher specific growth rate and thus minor generation time under the established experimental conditions. These values are comparable to those reported by Gorbach \& Goldin, (1991) who reported generation time of one hour for lactobacilli.

Acid and bile tolerance: It is important that the probiotic microorganisms are able to reach the GIT and remain viable there for $4 \mathrm{~h}$ or more (Marshall, 1997). Figure 1 shows the results corresponding to acid tolerance assay at $\mathrm{pH} 3$ for the strains. Strain LB-12 was able to achieve small cell concentration increments during $24 \mathrm{~h}$ of fermentation. Strain B/103-1-5 showed a lower viable cell counting during the same fermentation time. However it maintained an acceptable final cell concentration level. These results are comparable to those reported by Conway (1987).

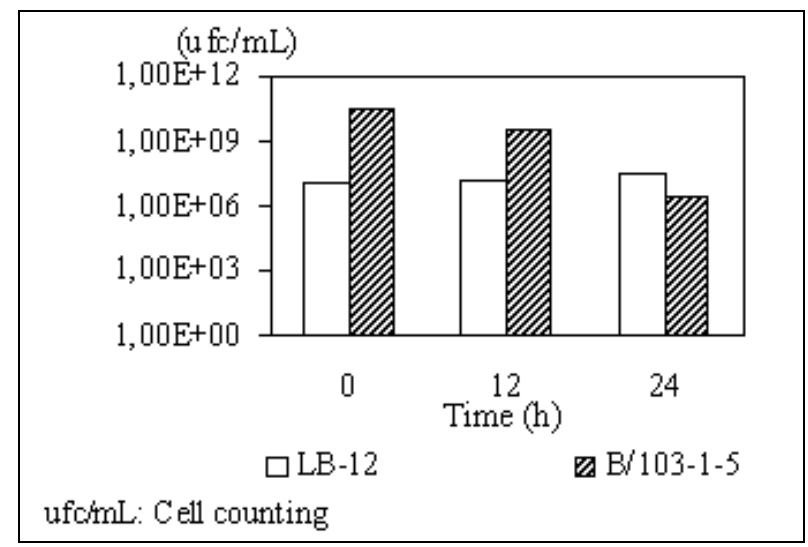

Figure 1 - Stability of LB-12 and B/103-1-5 strains in acid presence at laboratory level.

Bile addition effects on the evaluated strains are represented in Figure 2. Strain LB-12 was able to grow and stay viable in the presence of bile although a diminishing of cell concentration was observed when this behaviour was compared with the control. Nevertheless, the manifested behaviour allowed to predict the potentiality of this strain as a probiotic, since it was able to grow in a bile concentration similar to those existing in the small intestine.

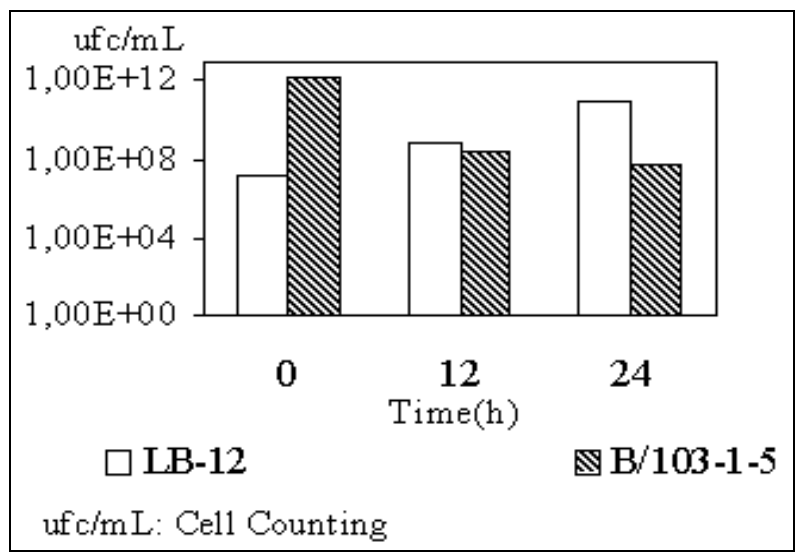

Figure 2 - Stability of LB-12 and B/103 - strains in bile presence at laboratory.

On the other hand, strain B-103-1-5 showed a different behaviour, diminishing its cell concentration during the microbial growth period; however, the final cell concentration value was adequate for the utilisation of this strain as probiotic.

Resistance to antibiotics: Figure 3 shows the optical density determinations._The behaviour of the strain B/103-1-5 appeared very similar to those obtained by viable cells counting, showing a maximal O D. after $12 \mathrm{~h}$ of cultivation followed by a decrease in the absorbance during the remaining incubation time. These results coincided to those reported by Mattila-Sandholm (1999) who described that many Lactobacillus strains were able to survive in the presence of antibiotic.

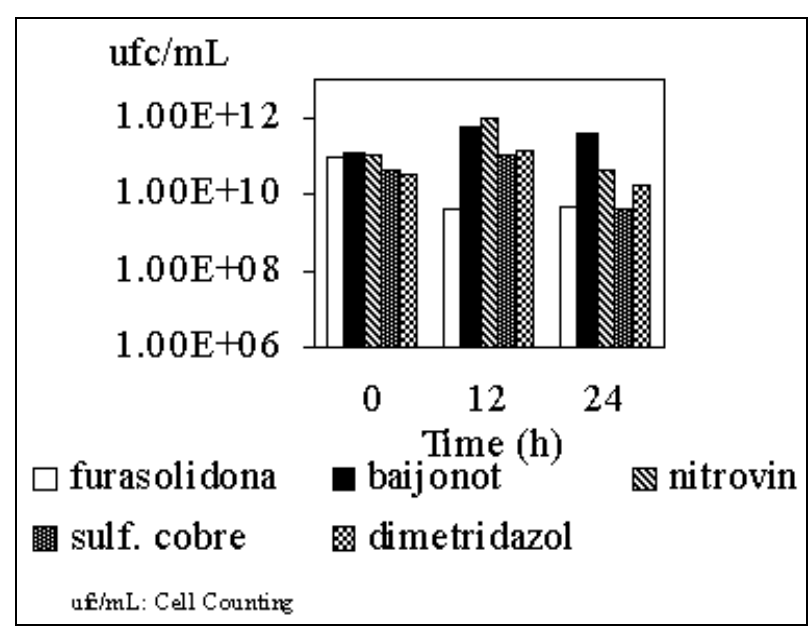

Figure 3 - Stability of B/103-1-5 strain in antimicrobial substances presence 
The presence of Baijonot produced a viable cells increment during the first 12 hours of fermentation, then the culture stayed practically stable until the end of the fermentation period. The rest of the evaluated antimicrobial substances influenced B/103-1-5 culture in a similar way to that of Baijonot.

Table 2 shows the results corresponding to the parameters estimated from the growth kinetic of both evaluated strains in fermentators. It was observed that the values obtained were in coincidence with the results at laboratory level.

Table 2 - Specific growth rate and generation time of LB12 y B/103-1-5 strains at fermentators scale.

\begin{tabular}{lccc}
\hline Strain & $(\boldsymbol{\mu}), \mathbf{h}^{-\mathbf{1}}$ & $\begin{array}{c}\text { Correlation } \\
\text { Coefficient }\end{array}$ & $\mathbf{T}_{\mathbf{G}}(\mathbf{h})$ \\
\hline LB-12 & 0.5435 & 0.9940 & 1.2 \\
B/103-1-5 & 0.5120 & 0.9850 & 1.3 \\
\hline
\end{tabular}

$\mu$ : Specific growth rate $\mathrm{T}_{\mathrm{G}}$ : Generation time

Figure 4 shows the growth curves for the two strains in the presence of acid. It was observed that between 8 to $12 \mathrm{~h}$, both strains possessed an adequate behaviour referred to the proposed objective. Strain LB-12 exhibited a superior behaviour in relation to growth rate, productivity and cell concentration when it was compared with strain B/103-1-5.

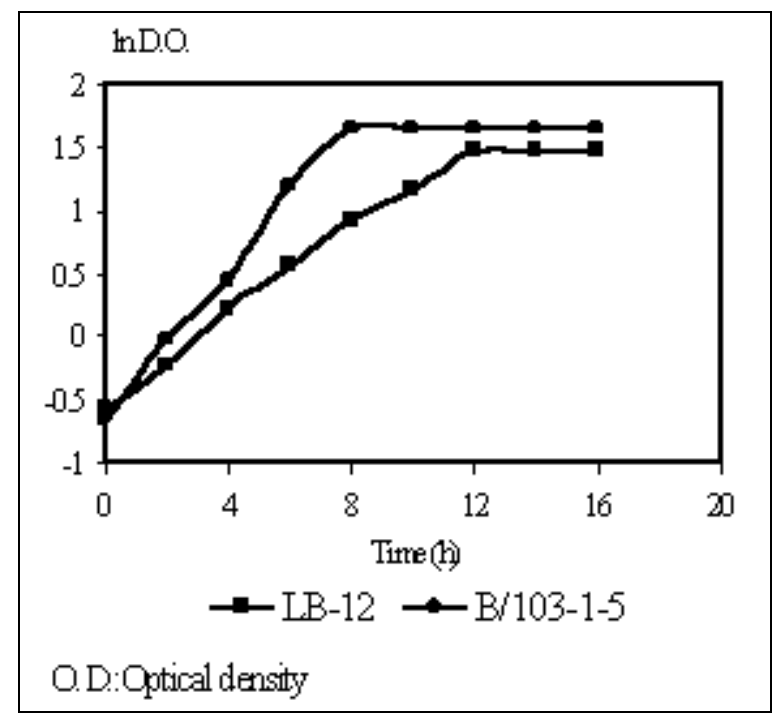

Figure 4 - Growth of LB-12 and B/103-1-5 strains in acid media at fermentators

The results achieved in relation to the growth rate, generation time, tolerance to acid and bile and antimicrobial substances indicated that the LB-12 and B/103-1-5 strains presented a good potential for being used as probiotics.

\section{RESUMO}

Foram realizados estudos "in vitro" para selecionar cepas de Lactobacillus com características probióticas. Duas cepas de Lactobacillus foram avaliadas quanto as características específicas que definem sua potencialidade como probióticos (velocidade específica de crescimento, tempo de geração, e resistência a ácido, bile e substâncias antimicrobianas). Os testes "in vitro" indicaram que ambas as cepas apresentaram um grande potencial para ser utilizadas na obtenção de probióticos.

\section{REFERENCES}

Brizuela, M. A.; Serrano, P.; Perez, Y.; Iglesias, I.; Rodriguez, R. y Zuaznaba, Z. (1998), Evaluación preliminar de cepas de bacterias ácido lácticas para su uso en la obtención de probióticos. Rev. LABORATActa, 2, 55-58.

Conway, P. L.; Gorbach, S. L. and Goldin, B. R. (1987), Survival of lactic acid bacteria in the human stomach and adhesion to intestinal cells. J. Dairy Sci., 70, 1-12.

de Man, J. C.; Rogosa, M. and Sharpe, M.E. (1990). A medium for the cultivation of lactobacilli. J. Appl. Bacteriol., 32, 130-135.

Delbecque, J. (1991), Ecología microbiana intestinal, bioregulación y aplicaciones prácticas. Anaporc, 102, 32-52.

Fuller, R. (1992), Problems and Prospects. InProbiotics: the scientific basis, ed. Fuller, R. Chapman \& Hall, London. pp. 377-386.

Gorbach, S. L. and Goldin, B.R. (1991), Lactobacillus acidophilus United States Patent, (5): 32, 399.

Hoyos, G. (1997), Aplicación de la biotecnología en la producción animal: La experiencia mexicana de una década. Memorias del $1^{\text {er }}$ Simposio Mexicano sobre Probióticos (pp 131-148). Junio 18-20, 1997. Ciudad Universitaria México, D.F.

Marshall, V. M. (1997), How far does Lactobacillus acidophilus meet the requirements of a probiotic organism?. Memorias del $1^{\text {er }}$ Simposio Mexicano 
sobre Probióticos (pp 73-80). Junio 18-20, 1997. Ciudad Universitaria, México D.F.

Mattila-Sandholm, T.; Mättö, J. and Saarela, M. (1999), Lactic acid bacteria with health claims-interactions and interference with gastrointestinal flora. Int. Dairy Journal 9, 25-35.

Miller, G. L. (1959), Use of dinitrosalicylic acid reagent for determination of reducinng sugar. Analyt. Chem., 31, 426-428.

Ouwehand, A.C.; Kirjavainen, P.V.; Shortt, C. and Salminen, S. (1999), Probiotics: mechanics and established effects. Int. Dairy Journal 9, 43-52.
Pascual, M.; Garriga, M.and Morfort, J. M. (1996), Los probióticos en la alimentación animal. Eurocarne, 44, 46-53.

Smoragiewicz, W.; Bielecka, M. and Boutard, A. (1993), Les probiotiques. Can. J. Microbiol,39,10891095.

Received: May 10, 1999; Revised: July 29, 1999; Accepted: March 24, 2000. 